\title{
Covid-19 Pandemi Döneminin Tüketicinin Tüketim Alışkanlıkları ve Tüketim Mekânlarına Bakış Açısı Üzerindeki Etkisi
}

\author{
Birsu Ece Kaya ${ }^{1}$ \\ ORCID: 0000-0001-8834-6732
}

\author{
İkbal Erbaş² \\ ORCID: 0000-0002-6327-1399
}

Öz

Üretim ve tüketim faaliyetleri tarih boyunca her dönemde farkl şekillerde insanların yaşamında yer almıştır. Küreselleşme ve kapitalizm, üretim ve tüketime yönelik faaliyetlerin farklı bir boyuta taşınmasina neden olmuştur. Her bireyi tüketici olarak değerlendiren kapitalist sistem satın alma ve tüketmeyi teşvik ederek devamlilı̆̆ın sürdürmekte, bireylerde alışkanlıklar ve bağımlılıklar yaratılarak tüketim kültürü oluşturulmaktadır. Illk olarak 2019 yılında karşılaşılıp tüm dünyaya yayılan Covid-19 virüsü, toplumların gündelik yaşamını etkilemekte, yaşam tarzında ve tercihlerinde değişikliklere sebep olmaktadır. Bu çalışmanın amacı, Covid-19 virüsü kaynaklı pandemi dönemi sürecinde kişilerin tüketim alışkanlıklarındaki ve tüketim mekanı tercihlerindeki değişimi sorgulamaktır. Çalışma, konu ile ilgili kavramsal çerçeve ve anket uygulamasını içeren iki ana bölümden oluşmaktadır. Çalışmanın sonucunda elde edilen bulgular, Covid-19 salgınından sonra bireylerin tüketim alışkanlıklarının ve tüketim mekanı tercihlerinin değgiştiğini, tüketicilerin online alışveriş sitelerini ve uygulamaların să̆hlk açısından daha güvenli bulduklarını ortaya koymaktadır. Çalışma sonuçlarının kalıı hale gelebilecek yeni tüketim alışkanlıklarına dikkat çekerek, yeni mekanların tasarlanması ve mevcut tüketim mekanlarında fiziksel ve sosyal düzenlemelerin uygulanması hususunda yapılacak gelecekteki çalışmalara altlık oluşturması hedeflenmektedir.

Anahtar Kelimeler: tüketim kültürü, tüketim alışkanlıklan, tüketim mekanlan, Covid-19, pandemi

\footnotetext{
${ }^{1}$ Doktora Öğrencisi, Akdeniz Üniversitesi, E-mail: birsuece@gmail.com

${ }^{2}$ Doç. Dr., Akdeniz Üniversitesi, E-mail: ierbas@akdeniz.edu.tr

idealkent (c) Kent Araştırmaları Dergisi (Journal of Urban Studies)

http://idealkentdergisi.com

Geliş Tarihi Received Date: 12.02.2021 Kabul Tarihi Accepted Date: 05.09.2021
} 


\title{
The Effect of Covid-19 Pandemic Period on Consumer's Consumption Habits and Perspective On Consumption Spaces
}

\author{
Birsu Ece Kaya ${ }^{3}$ \\ ORCID: 0000-0001-8834-6732
}

\author{
İkbal Erbaş4 \\ ORCID: 0000-0002-6327-1399
}

\begin{abstract}
Production and consumption activities have taken place differently in people's lives throughout history. Globalization and capitalism have caused production and consumption practices to be moved a different dimension. The capitalist system, which evaluates each individual as a consumer, maintaines its continuity by encouraging to purchase and consume, and consumption culture is constituted by creating habits and addictions on individuals. Covid-19 virus, which was firstly encountered in 2019 and spread all over the world, affects the daily life of societies and causes chages in preferences. The aim of this study is questioning what kind of changes occured in people's consumption habits and consumption space preferences during the pandemic period caused by the Covid-19 virus. The study consists of two main sections that include the conceptual framework and questionnaire practice. According to the findings obtained as a result of the study, it could be said that after the Covid-19 epidemic, individuals' consumption habits and consumption space preferences changed, and they found online shopping sites and applications safer in terms of health. In this direction, it is expected that new consumption habits that could become permanent, the emergence of new spaces and the implementation of physical and social regulations in existing consumption spaces.
\end{abstract}

Keywords: consumption culture, consumption habits, consumption spaces, Covid-19, pandemic

\footnotetext{
${ }^{3}$ Ph.D. Student, Akdeniz University, E-mail: birsuece@gmail.com
}

${ }^{4}$ Assoc. Prof., Akdeniz University, E-mail: ierbas@akdeniz.edu.tr

idealkent (c) Kent Araştırmaları Dergisi (Journal of Urban Studies)

http://idealkentdergisi.com

Geliş Tarihi Received Date: 12.02.2021 Kabul Tarihi Accepted Date: 05.09.2021 


\section{Giriş}

Üretim ve tüketim tarih boyunca her dönemde farklı şekillerde insanların yaşamlarında yer almış; kapitalizm, endüstrileşme, küreselleşme gibi sistemler üretim ve tüketim ilişkilerini tüm dünyada yeni bir seviyeye taşımıştır. Anthony Giddens (1994), modern toplumların yapısını incelerken kapitalizm ve endüstriyalizmi modern toplumların modern kurumlarıyla ilişkisi olan "örgütsel kümeler" olarak tanımlamıştır. Küreselleşme ve kapitalizm üretim ilişkilerini yeniden ele alıp tüketim ilişkilerinin yeniden düzenlenmesini zorunlu kılmış, üretim ve tüketime yönelik uygulamalar farklı bir boyuta taşınmıştır. Küreselleşme ve serbest piyasa ekonomisi güçlü şirketlerin uluslararası düzeyde üretim yapmasına olanak sağlarken tüketim piyasasında da daha geniş coğrafyalara ve kitlelere pazarlama yapma imkanı sağlamıştır. Bu noktada, günümüz toplumlarının geçmişten farkı, üretimden çok tüketime vurgu yapılması ve harcamanı öncelenmesidir (Kadığlu, 2014, s.41).

Yeni piyasa toplulukların tüketim algıların değiştirerek farklı kültürlere sahip toplulukların ortak ürünlere talep göstermesini sağlamıştır. Bu doğrultuda, kapitalist sistem dünyanın her köşesindeki bireyleri tüketici olarak ele almakta ve tüketiciler sayesinde sistemin devamlılı̆̆ını sağlamaktadır. Kapitalist ekonomi sistemi devamlılığını sağlamak için tüketimi sadece gereksinim ve kullanımın doğal süreçlerine bırakmaz; tüketimi sürekli canlı tutmayı, yeni ihtiyaçlar yaratmayı hedeflemektedir (Yırtıcı, 2002, s.13). Bu ihtiyaçlar karşısında tüketicilerin alışkanlıkları şekillenmekte ve tercihleri birbirinden farklılık göstermektedir.

Mimarlık disiplininin ürünü olan mekan da kimi zaman toplumsal yaşam içinde çağdaş tüketim kalıpları ile ilişkili olarak üretilen ve tüketilen bir nesne olurken, bazen de tüketim eyleminin mekanıdır (Yırtıc1, 2002, s.9-11). Tüm toplumsal, kültürel, ekonomik değişmelerle birlikte yeni koşullara uygun olarak mimarlık ve inşaat sektörü yeni tüketim mekanları geliştirmiştir. Gündelik hayatta gerçekleşen değişiklikler, yaşanan olaylar yeni tüketim mekanlarının üretilmesine sebep olurken, sermayenin oluşturduğu yeni tüketim mekanları da bireylerin gündelik hayatında ve alışkanlıklarında değişikliklere sebep olmaktadır.

2019 yılında Çin'de ortaya çıkan “Covid-19 virüsü" salgına dönüşerek salgın ile geçirilen süre boyunca dünyada her alanda köklü değişikliklere neden olmuştur. Salgın insandan insana solunum ve temas yoluyla bulaşarak dünyanın bütün kentlerinde hızla yayılmıştır. Türkiye'de 2020 yılının Mart ayında ilk vakanın görülmesiyle birlikte devlet ve Sağlık Bakanlığı tarafından 
gerekli önlemler alınmaya başlanmış, vatandaşların gündelik hayatında değişikliğe gitmesi zorunlu kılınmıştır. Bu süreçte bireylerin mekansal tercihlerinin ve ihtiyaçlarının değişmesi kaçınılmaz olmuştur. Ortaya çıkan bu değişimlerden bazılarının geleceğe yönelik kalıcı etkilere sebep olması alışılagelen tasarım yaklaşımlarının ve ilkelerinin de yeniden gözden geçirilmesini gerekli kılmaktadır.

Araştırma konusu ile ilgili literatür incelendiğinde, tüketim toplumu, tüketim alışkanlıkları ve alışveriş merkezleri üzerinde yoğunlaşmak üzere tüketim mekanların kapsayan çalışmaların olduğu, Covid-19 virüsünün toplumun yaşam tarzı ve satın alma tercihlerine etkisi üzerine yapılmış çalışmaların olduğu görülmüştür (Bayır, 2021; Danışmaz, 2020; Duygun, 2020; Kayabaşı, 2020). Çakıroğlu, Pirtini ve Çengel (2020), Covid-19 sürecinde tüketicilerin temel ihtiyaçlara yöneldiğini, çevrimiçi alışverişin arttığını, dijital platformların daha çok kullanıldığını ve sosyal sorumluluk projelerinin arttı̆̆ını ifade etmişlerdir. Bu etkinin uzun süreçte devam etmesinin tüketici olan toplumların yaşam tarzında kalıcı değişikliklere neden olacağı sonucuna varmışlardır. İnce ve Kadığlu (2020), Covid-19 salgın sürecinin tüketici davranışlarında neden olduğu değişimleri incelemiş ve tüketicilerin stoklama eğilimlerinin ve online satın alma davranışlarının arttı̆̆ sonucunu elde etmişlerdir. Kotler (2020), Covid-19 pandemi sürecinden sonra toplumların neye ihtiyacı olduğunu ve neyi tükettiğini yeniden ele alacağını ve bu nedenle yeni tüketici eğilimleri ve davranışlarının ortaya çıkacağını ifade etmiştir. Erbaş (2021) yaşanan bu süreçte mimarların kritik önemine dikkati çekerken, Özcü ve Atanur (2020) Covid-19'un kent yaşamına etkisini değerlendirmiştir. Ancak yapılan incelemelerde Covid-19 pandemi dönemi öncesi ve sonrası tüketim alışkanlıkları ve tüketim mekanı tercihlerini inceleyen yeterli çalışmaya ulaşılamamıştır.

Bu bağlamda çalışmanın amacı, Covid-19 virüsü ve salgın sürecinin gündelik hayatı ve alışkanlıkları etkilemesi sebebiyle, kişilerin tüketim alışkanlıklarındaki ve tüketim mekanı tercihlerindeki değişimi ve yönelimi sorgulamaktır. Bu amaç doğrultusunda, çalışma kapsamında tüketim kültürü, tüketim toplumu, tüketim alışkanlıkları ve tüketim mekanları kavramları ile ilgili kavramsal bir çerçeve oluşturularak Türkiye'de yaşamakta olan bireylerin Covid-19 pandemi döneminde tüketim alışkanlıkları ve tüketim tercihlerini tespit etmek amacıyla yapılan anket çalışmasının bulguları değerlendirilmiştir. Bu araştırmada, tüketicilerin Covid-19 öncesi ve sonrasında tüketim alışkanlığı ve mekanı tercihlerinin karşılaştırılarak tüketim mekanında değiştirilmesi veya iyileştirilmesi beklenen fiziksel, sosyal özelliklerin ortaya konulması çalışmanın özgün yönünü oluşturmaktadır. 


\section{Tüketim Kültürü ve Tüketim Toplumu}

Bilgi, kültür, duygular, ihtiyaçlar - kısacası tüm insani yetiler - üretimin düzeni içinde metalar olarak birleştirilirler ve satılabilsinler diye üretici güçler olarak maddesel form alılar. Benzer biçimde bugün tüm arzular, projeler, istekler, tüm tutku ve ilişkiler, satın alinan ve tüketilen nesneler ve işaretler olarak soyutlanıyor ya da maddeleştiriliyor. (Karl Marx, akt. Baudrillard, 2002, s.69).

Tüketim, kültür, iletişim ve tarihin her seviyesine ulaşabilen, nesne ile bireyler arası ilişkilerin ötesine geçen ve sınırları olmayan sistematik bir çalışmanın pratiği olarak tanımlanabilmektedir (Baudrillard, 2002, s.71-72). Zaman içinde üretim ve tüketimin farklılaşması ve bireyleri farklılaştırması sistemin sınırsızlığını ve sonsuzluğunu sağlamaktadır (Baudrillard, 1997, s.68). Üretim ve tüketim sürdürülebilirliğini sağlamak için tüketim kültürü, tüketici ihtiyaçlarının ilke olarak sınırsız ve doyurulmaz olduğu düşüncesine dayanmaktadır (Çınar ve Çubukçu, 2009, s.280). Baudrillard'a göre (1997, s.71), büyüme topluluğunun devamlılığı için hem mal üretilmesi hem de ihtiyaç üretilmesi gerekmektedir; mal üretimi ekonomik üretkenliğin bir işlevi iken, ihtiyaç üretimi ise toplumsal farklılaşmanın aracıdır.

Kişilerin bireysel olarak gerçekleştirdikleri tüketim eylemi toplu olarak değerlendirildiğinde toplumun "tüketim eğilimi" ortaya çıkmaktadır ve toplumun tüketim eğilimi toplumun gelir yapısı ve gelir dağılımına bağlı olduğu gibi ihtiyaçların niteliğine ve şiddetine göre belirlenmektedir (Kadığlu, 2014, s.15). "Tüketim toplumu" kavramı ise tüketim merkezli yeni bir toplumsal yapılanmayı ifade etmektedir (Yırtıcı, 2002, s.10). Çınar ve Çubukçu'nun ifade ettiği üzere (2009, s.279) tüketim toplumu, kapitalist sistemin hakim olduğu toplumlarda söz konusudur ve tüketim toplumunun ayırt edici özelliği, ihtiyaçlara yönelik tüketim faaliyeti gerçekleştirmek yerine, tüketimin kendisinin bir amaç ve ihtiyaç haline gelmesidir. Toplumsal bir varlık olarak insanın temel ve bedensel ihtiyaçları niceliksel olarak sınırlıdır, ama sosyal ve kültürel sistemin olanakları sınırsızdır (Baudrillard, 1997, s.73). Değişen zaman ve koşullar tüketim eğilimlerinin de değişmesine sebep olmuş, tüketim zorunlu ihtiyaçların karşılanmasından farklılaşarak sosyal tatmin, mutluluk aracı ve statü göstergesi olarak devamlılı̆̆ını sürdürmektedir.

Siyasal, ekonomik ve sosyal çevrede gerçekleşen değişimler toplumsal yapılarda birtakım yansımalara neden olmaktadır. İşücü yapısı, teknoloji, ekonomik krizler, sosyal eğilimler, dünya politikaları ve rekabet gibi sistemde değişikliğe neden olan etkenler örgütsel yapılanmalarda ve toplumun gündelik hayatında değişikliğe sebep olmaktadır. (Özkalp ve Kırel, 2018, s.430). 
Normal şartlarda, örgütsel değişim planlı olarak belirli bir amacı gerçekleştirmek üzere düzenlenmektedir (Can, Aşan Azizoğlu ve Miski Aydın 2015, s.409); fakat, Covid-19 salgınının bir anda tüm dünyaya yayılması değişimlerin plansız ve hızlı bir şekilde gerçekleşmesine neden olmuştur. Covid-19 salgını sürecinde, bireylerin ve toplumların normalde direnç gösterebilecekleri durumları bu dönemde hızlıca kabullendiği ve yeni alışkanlıklar geliştirdikleri görülmektedir. Bu bağlamda, Covid-19 pandemi dönemi, toplumların tüketim tercihleri ve yönelimlerinde farklılıkların oluştuğu bir değişim dönemi olarak adlandırılabilir ve bu sürecin sermaye ve mekansal düzenlemelerdeki yansımaları ve düzenleyici gücü hala devam etmektedir.

Dünya çapında çeşitli etkilere sebep olan Covid-19 salgınının, tedavisi uygulanıp yayılma hızı ve etkisi azaltılsa da toplumların yaşam ve davranış biçimlerinde bazı kalıcı değişikliklere yol açacağı görülmektedir. Salgın sürecinde izolasyon amacıyla evde çalışılması, eğitim görülmesi, çevrimiçi sosyalleşme ve çevrimiçi alışverişler geçirilen süreye paralel olarak bu faaliyetlerin içselleştirilmesine neden olmakta ve bu yönelimin kalıc hale gelmesinin kaçınılmaz olacağı öngörülmektedir. Temizlik, hijyen, kalabalıktan kaçınma ve sosyal izolasyonun sağlanmasına eskiye göre daha dikkat ediliyor olması Covid-19 sonrası dönemde de eğlence yerleri, alışveriş merkezleri, restoranlar ve spor salonları gibi toplu kullanım sunan kalabalık mekanların daha az tercih edilmesine neden olmaktadır (Çevik Tekin, 2020, s.2342). Bu değişimin bir sonucu olarak söz konusu mekanlarda bazı fiziksel düzenleme ve iyileştirmelerin yapılması gerekli olacaktır. Değişen ve kalıcı hale gelen yönelimler Covid-19 sonrası toplumunun başta sosyal yapısı olmak üzere tüketim yapısı, mekansal tercihleri ve talepleri üzerinde etkili olacaktır.

\section{Tüketim Alışkanlıklarının Ortaya Çıkması}

Gündelik yaşamında insanı çevreleyen her şey -evler, mimari, konut örgütlenmesi, mobilyalar ve ev eşyaları- ayn zamanda kültürün de parçasıdır ve zevki etkiler... (Georgy Alexandrov, akt. Lefebvre, 2010, s.51).

Ekonomik anlamda tüketim, insanların ihtiyaçlarını karşılamak için mal veya hizmetlere bedel ödeyerek sahip olmaları veya kullanmalarıdır (Kadığlu, 2014, s.15). Toplumsal ihtiyaçlar yaşlara, cinsiyetlere, gruplara ve farklı etkenlere göre bireysel ve kolektif ihtiyaçlar olarak farklılaştırılmıştır (Lefebvre, 2010, s.38). İnsanlarda tüketim eylemine yönelten temel güdü bireysel ihtiyaçlardır ve sürekli değişen, çoğalan ihtiyaçlar tatmin edildiğinde haz duygusu verirken, tatmin edilmediğinde kişide sıkıntı yaratmaktadır (Kadığlu, 
2014, s.16). Bu durum kapitalizm ve küreselleşmenin bir sonucudur; üretimin seri üretim ile hızlandırılması, ürünlerin tüm dünyaya daha uygun fiyatlarla hızlıca yayılması bireylerin gündelik hayatında ilişki kurduğu nesnelerle ilişkisini bütün olarak değiştirmiş, nesnelere ve satın almaya bağımlılığı artmıştır.

Kadıŏlu'nun (2014, s.17) ifade ettiği üzere, neden tüketiriz sorusunun cevabını ihtiyaçları yaratan güdülerde aramak mümkündür. Bu doğrultuda, tüketim eylemine neden olan temel güdüler; yalın ihtiyaçlar, sosyalleşme güdüsü, kendini ifade etme güdüsü, tüketim zorlayıcıları ve öğrenilmiş tüketim güdüleridir. Bu durumda, bireyleri tüketime yönlendiren sebepler temel gereksinimler olabildiği gibi toplumsal durum ve özendiriciler de olabilmektedir.

Baudrillard'a göre, tüketimin amacı nesneler ve araçların dolaşımı ve tüketilmesi değildir; nesneler ihtiyacı karşılamaya yöneliktir ama bu durum sadece tüketimin önkoşuludur. Nesneler artık bir işleve veya tanımlı bir ihtiyaca bağlı değildir; tüketimin asıl amacı, nesnelerin maddeselliği değil, yarattığı farklılıktır (Baudrillard, 1997, s.89; Baudrillard, 2002, s.68). Sistem, tüketimi devamlı kılmak için ürünleri hem temel hem de sosyal ihtiyaçlara yanıt verecek şekilde algı oluşturarak pazarlamaktadır. İhtiyaçlar hakkındaki söylemler mutluluk arayışına dayandırılmaktadır ve reklamların arka planında yer alan mutluluk algısı tüketim kültürünün bir araç haline gelmektedir.

Bireylerin tüketim tercihleri ve satın alma eylemleri bireyin bulunduğu ekonomik ve sosyal konum, gelir durumu ve hayat tarzı hakkında bilgi vermektedir. Her birey gidermek zorunda olduğu temel gereksinimlere yönelik tüketime yönelirken ait olmak istediği sosyal grubun gerektirdiği tüketim alışkanlıklarını da sürdürmektedir. Gıda, barınma, giyim gibi temel yaşamsal ihtiyaçların karşılanmasına yönelik gerçekleştirilen tüketim "yararcı tüketim" olarak adlandırılırken temel ihtiyaçların ötesinde kişisel ve duygusal tatminleri karşılayan ihtiyaçları gidermeye yönelik gerçekleştirilen tüketime "hazcı tüketim" denilmektedir (Kadığlu, 2014, s.21). Kişiler sahip oldukları gelir durumu ve bulundukları toplum yapısı gibi etkenlere bağlı olarak yararc1 ve hazcı tüketimlerini gerçekleştirmektedir. Bulunduğumuz toplumlarda sadece temel ihtiyaçlarını karşılamak için yararcı tüketim gerçekleştiren "anti-tüketiciler" de bulunmaktadır. Anti-tüketiciler hayatın basitleştirilmesi, doğanın ve doğal kaynakların korunması, var olanların korunarak sürdürülmesi gibi farklı sebeplerle hazcı tüketime karşı çımaktadır (Kotler, 2020).

Zeren ve Gökdağlı'ya göre (2017, s.43), bazı tüketiciler için alışveriş eylemi hayatlarındaki stresleri ve gerilimleri azaltmaya, unutmaya yönelik gerçekleştirdikleri kontrol edilemeyen, takıntı haline gelmiş davranışlardır. Covid19 sürecinde, tüketicilerde hem yararcı hem de hazcı tüketim eğiliminin var 
olduğunu söylemek mümkündür. Bazı bireylerin, pandeminin yarattı̆ı stres ve kaygıyı azaltmak, kısa süreliğine dikkatini başka şeylere vermek amacıyla online alışverişin sunduğu kolaylık ve imkanlardan yararlanarak ihtiyacı olmayan ürünleri satın alma eğilimi gösterdiği söylenebilir. Tüm salgın sürecinin tüketicilerin alışkanlıklarında ve tercihlerinde kalıcı hale gelecek bazı değişikliklere sebep olduğu düşünülmektedir. Diğer bir açıdan, insanların salgın süresince edindikleri tecrübeler doğrultusunda, daha iyi bir yaşama sahip olmak için iş hayatı, aileleriyle geçirdikleri vakit ve boş zamanları arasında öncekinden farklı bir denge oluşturacağı ve post-tüketimcilik döneminin oluşacağ tahmin edilmektedir (Kotler, 2020).

Covid-19 salgını süreci de Türkiye'de ve tüm dünyada sağllğı gündem haline getirmiş, sağlı̆̆ın korunmasını önceleyen tüketim tercihleri ön plana çıkmıştır. Bu tercihler bireylerin hem ürün hem de tüketim mekanları seçimlerini kapsamaktadır. Kotler'e göre (2020), salgından kaynaklanan yoksunluk ve kayg1, tüketicilerin neyi tükettiğini, ne kadar tükettiğini ve ürünleri nereden temin ettiğini sorgulamasına sebep olmaktadır. Covid-19 salgını döneminde de yararcı ve hazcı tüketimler farklı sebepler ve motivasyonlar sebebiyle gerçekleştirilmiş, tüketim kültürü ve alışkanlıkları değişen tercihler ve mekanlarda devam ettirilmiştir.

Biz mi tüketime bağımlıyız, yoksa tüketim mi bize bağıml??5 (Kotler, 2020).

\section{Tüketimin Mekansal Örgütlenmesi}

Tarih boyunca insanlar farklı ekonomik, toplumsal, sosyo-kültürel aşamalardan geçmiş olsalar da tüketim eylemlerini gerçekleştirecekleri alanlar düzenleyerek tüketim mekanlarını oluşturmuşlardır. Üretim ilişkilerinin toplumsal hayat içinde yer bulması mekansal varlıklar ile sağlanmaktadır ve kapitalist devletin rasyonel temellerini oluşturan meslekler ve disiplinler mekan temsillerini oluşturarak sermayenin mekanlarını üretmektedir (Arslan Avar, 2009 , s.8,12). Sanayi devrimine kadar dükkanlar, haller, çarşılar vb. tüketim için düzenlenmiş mekanlar iken kentleşme ve sanayi devrimi sonrasında tüketim ile birlikte sosyalleşmeyi ve farklı kullanımları bir arada sunan yeni tüketim mekanları üretilmeye başlamıştır. İnsanların çalışma saatleri ile dinlenme, beslenme, uyku gibi temel ihtiyaçlarını karşılama saatleri dışında tanımlanan serbest zamanları alışveriş yapma, restoranda yemek yeme, seyahat etme, spor yapma gibi tüketimi destekleyen çeşitli faaliyetlerle bütünleş-

${ }^{5}$ Orijinal versiyonu: "Is our addiction to consuming, consuming us?". 
tirilmiştir (Çakıroğlu ve diğerleri, 2020, s.86). Günümüz toplumundaki tüketim mekanları da temel ihtiyaçların giderilmesine ek olarak sosyal ve kültürel gereksinimleri karşılamayı, boş zamanları değerlendirmeyi de olanaklı kılacak şekilde düzenlenmektedir. Aslında tüm bunlar toplumda alışkanlıklar yaratmak ve tüketimi devamlı kılmak için gerçekleştirilen sosyal, kültürel, ekonomik ve mekansal düzenlemelerdir.

1990'l y yıllardan itibaren küresel ekonomik ilişkilerin bir parçası haline gelen Türkiye'nin özellikle büyük kentlerinde toplumsal süreçte ve gündelik hayatta meydana gelen değişiklikler kent mekanında yeni tüketim mekanlarının ortaya çıkmasına sebep olmuştur. Öncelikle, yabancı ve yerel sermayenin hegemonyasında olan hipermarketler geniş ürün yelpazesi ve pazarlamayı kolaylaştırıcı unsurlar içermesi sebebiyle küçük üreticinin ve küçük esnafın ticaret hacminin azalmasına neden olmuştur (Özbek Sönmez, 2002, s.32,34). 1960'lı yıllardan itibaren artıs göstermeye başlayan alışveriş merkezleri de tüketim kültürünün mekansal örgütlenmesinin bir parçasıdır.

Günümüz koşullarında elde edilen teknolojik gelişmeler yeni toplum düzeninin gündelik hayatına uyumlu olacak ve gündelik hayatında tüketimi kolaylaştıracak şekilde sanal tüketim ortamlarını düzenleyerek yeni bir tür tüketim mekanının ortaya çıkmasına neden olmuştur. Gittikçe artan çalışma saatleri ve boş zamanların azalması, trafik gibi ulaşım sorunlarının ortaya çıması toplumun gündelik yaşamında yeni alışkanlıklar edinmesinde etkili olmuştur. Yeni yaşam tarzı ile kişiler sanal ortamlar üzerinden dünya ve diğer insanlar ile iletişim kurmaya, sosyalleşmeye ve alışveriş yapmaya başlamışlardır. Bu durum farklı sektörleri içerecek şekilde sanal tüketim mekanlarının düzenlenmesine ve yeni pazarlama stratejilerinin geliştirilmesine neden olmuştur.

Covid-19 salgını sürecinde sosyal izolasyonu sağlamak amacıyla evde daha çok vakit geçirilmesi ve ihtiyaçların evden dışarı çıkmadan karşılanmak istenmesi teknolojiden daha fazla yararlanılmasına neden olmuştur ve belki de bu süreçte edinilen alışkanlıklar gelecek dönemde sürekli hale gelecektir (Çakıroğlu ve diğerleri, 2020, s.95). Tedbir amaçlı olarak internet üzerinden evden çalışma ve evden eğitime yönelim arttığı gibi ihtiyaçların giderilmesinde de bazı kesimler için evden çıkmadan alışverişi çevrimiçi yapabilmek önem kazanmıştır. Bu bağlamda, çevrimiçi alışveriş için düzenlenen sanal ortamlar soyut bir mekansallık olarak düşünülebilir. Ama bu soyut mekanın arkasında alışveriş eyleminin gerçekleştirilebilmesi için dağıtım merkezleri, dağıtım ağları, ilişkili fiziksel mağazalar ve depolar gerekmektedir (Çakıroğlu ve diğerleri, 2020:93). Yani, sanal ortamdan yapılan alışveriş fiziksel 
olarak mevcut olan tüketim mekanlarının yok olması anlamına gelmemektedir, bu mekanlara ek olarak yeni mekansal düzenlemelerin yapılması gerekmektedir. Sistem, bu mekansal düzenlemelere bireyleri her koşulda tüketmeye motive edebilmek ve tüketimin devamlılığını sağlamak için ihtiyaç duymaktadir.

\section{Yöntem}

Covid-19 pandemi sürecinin tüketicinin mekansal tercihlerinde yarattığ1 etkileri değerlendirmek amacıyla çalışma kapsamında anket çalışması yapılmıştır. Tüketicilerin tercihlerini ve eğilimlerini anlamaya yönelik olarak hazırlanan anket üç bölümden oluşturulmuş ve toplam 22 soru sorulmuştur. İlk bölümde yaş, cinsiyet, eğitim durumu, çalışma durumu ve aylık gelir düzeyini içeren demografik bilgilere dair ifadelere yer verilmiştir. İkinci bölümde pandemi öncesi ve sonrasında tüketim alışkanlıklarını ve tüketim mekanı tercihlerini belirlemeye yönelik çoktan seçmeli sorular sorulmuştur. Üçüncü bölümde ise, Covid-19 salgınından sonra bireylerin alışveriş için gittikleri tüketim mekanlarında aradıkları fiziksel, sosyal özelliklere dair düşüncelerini ölçmek için kesinlikle katılıyorum, kesinlikle katılmıyorum vb. şekilde ifade edebilecekleri 5'li Likert ölçeği ile oluşturulmuş ifadelere yer verilmiştir.

Pandemi sebebiyle katılımcılarla yüz yüze olarak bir araya gelme imkanı düşük ve riskli olduğu için anket çalışması çevrimiçi olarak hazırlanmış ve internet ortamı üzerinden kartopu örneklem metodu ile farklı şehirlerde yaşayan farklı sosyal, ekonomik ve kültürel düzeylere sahip insanlara ulaştırılmıştır. Kartopu metodunda önce örneklem evrenindeki bir bireye ulaşılır, sonra o bireyin yardımı ile diğer bireye ulaşılır, daha sonra onların yardımıyla başka bireylere ulaşllarak hedeflenen örneklem büyüklüğüne ve çeşitliliğine erişmeye çalışılır (Böke, 2017, s.129). Çevrimiçi anket uygulaması Ankara, İstanbul, İzmir ve Antalya şehirlerinden başlayarak Türkiye'nin çeşitli illerine kartopu örneklem metodu ile dağıtılmıştır.

Asiamah, Mensah ve Oteng-Abayie (2017), genel popülasyon, hedef popülasyon ve erişilebilir popülasyon olmak üzere üç tür populasyon tanımlamaktadır. Genel popülasyon genellikle araştırma hedefleri tanımlanarak belirlenirken, hedef popülasyon belirli ilgi ve alakaları olan bireyler veya bir grup katılımcı olarak tanımlanır (Kotrlik ve Higgins, 2001; Asiamah ve diğerleri, 2017). Erişilebilir popülasyon ise araştırmaya katılmaya istekli ve çalışma zamanında mevcut olan hedef popülasyonun üyelerinden oluşmaktadır. Araştırmanın erişilebilir popülasyonunu kartopu örneklem metoduyla ulaşı- 
lan 18 yaşından büyük öğrenci, çalışan, çalışmayan ve emekli kişiler oluşturmuştur. 2021 yılının Ocak ayında çevrimiçi olarak uygulanan anket 212 kişiye ulaşılması ile tamamlanmıştır. Anketteki demografik bilgilerden elde edilen sonuca göre, katılımcıların \%33'ünün 0-3.000 TL aralığında düşük gelir düzeyine sahip olması ve \%10,4'ünün $10.001 \mathrm{TL}$ ve üzeri gelire sahip olması kat1lımcıların çoğunlukla düşük gelir grubuna dahil olduğunu göstermekte ve örneklem hakkında bilgi vermektedir. Anket çalışmasına dair araştırma hipotezlerini şu şekilde ifade etmek mümkündür:

1. Hipotez:

H0: Covid-19 salgınından sonra tüketim ihtiyaçları ve alışkanlıklarında değişiklik yoktur.

HA: Covid-19 salgınından sonra tüketim ihtiyaçları ve alışkanlıklarında değişiklik vardır.

2. Hipotez:

H0: Covid-19 salgınından sonra tüketim mekanı tercihinde değişiklik yoktur. HA: Covid-19 salgınından sonra tüketim mekanı tercihinde değişiklik vardır.

3. Hipotez:

H0: Covid-19 salgınından sonra tüketim mekanları arasında online alışveriş siteleri ve uygulamaları sağlık açısından daha güvenli bulunmamaktadır. HA: Covid-19 salgınından sonra tüketim mekanları arasında online alışveriş siteleri ve uygulamaları sağlık açısından daha güvenli bulunmaktadır.

Anket çalışmasının verilerinin analizi için IBM SPSS istatistik programı kullanılmıştır. Araştırmalarda uygulanan güvenirlik analizi, bir ölçme aracıyla aynı koşullarda tekrarlanan ölçümlerde elde edilen ölçüm değerlerinin kararlılığının bir göstergesidir ve 1951 yılında Cronbach tarafından geliştirilen alfa katsayısı 1-5 gibi sıralı puanlamalarda kullanılan bir iç tutarlılık yöntemidir. Tüm maddeler için ayrı ayrı hesaplanan veya ortalaması alınarak bulunan alfa değerinin oranı yapılan çalışmanın güvenilirlik durumunu belirlemektedir. Bu çalışmada, öncelikle 5'li Likert ölçeği ile oluşturulan ifadeler güvenilirlik analizinden geçirilmiştir. Cronbach's Alfa değeri 0,691 olarak hesaplandığından, kullanılan ölçeğin güvenilirliğinin orta düzeyde olduğu söylenebilmektedir. Demografik bilgileri ve 3 hipotezin boş ve alternatif hipotezlerini analiz etmek için frekans dağılımı analizi yapılımıştır. (Şekil 1). 

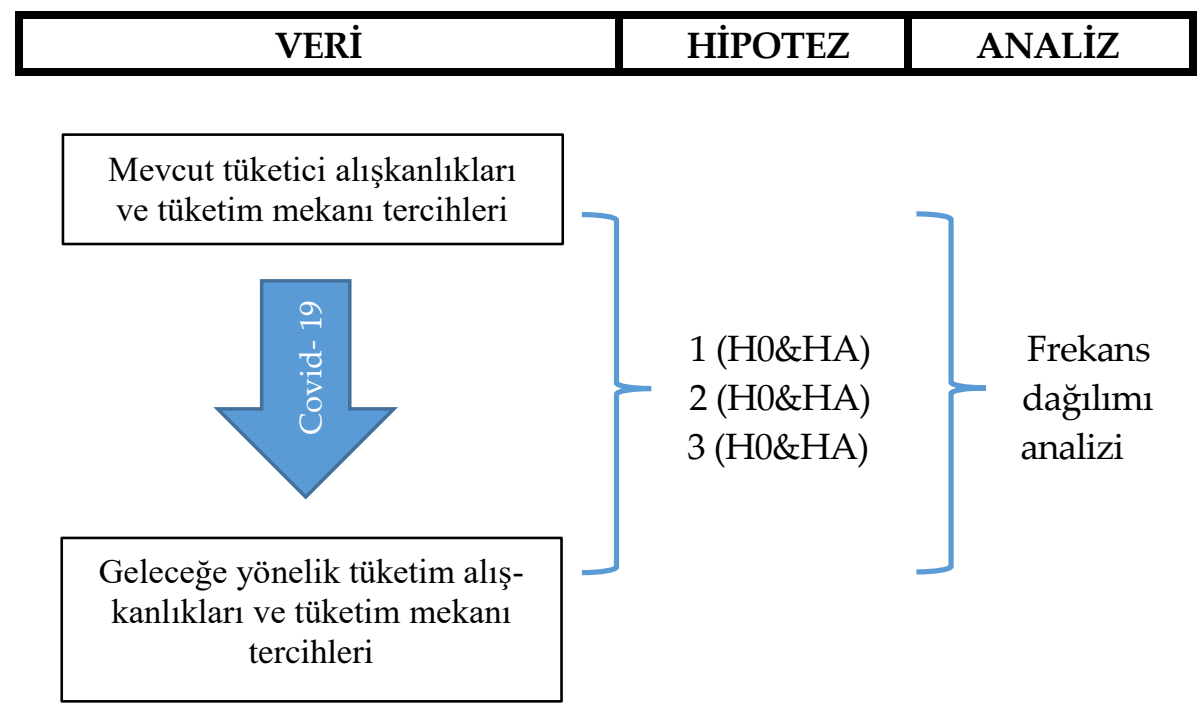

Şekil 1. Araştırma ve hipotezlerin ilişkisi şeması.

\section{Bulgular}

Bu bölümde, katılımcların demografik bilgilerine dair bulgulara, tüketim alışkanlıkları ve tüketim mekanı tercihi ölçme kriterlerine verilen cevapların frekans değerlerine, oluşturulan hipotezlerin testlerine ve çıkan sonuçların değerlendirilmesine yer verilmiştir.

\section{Demografik bulgular}

Tablo 1, ankete katılan bireylerin cinsiyet, yaş, eğitim durumu, çalışma durumu ve aylık gelir düzeyi bilgilerini içermektedir. Elde edilen verilere göre, katılımcıların \%65,1'inin kadın ve \%34,9 erkek olması sebebiyle kadın katılımcıların oranının daha fazla olduğu, $\% 40,1$ oranla 25 ve 34 yaş aralığındaki kişilerin en fazla katıldığı, eğitim açısından değerlendirildiğinde $\% 60,4$ oranla lisans mezunlarının büyük bir kısmı oluşturduğu, $\% 57,5$ oranla bireylerin yarısından fazlasının çalışmakta olduğu ve gelir düzeyinde çok büyük orantısal farklılıklar olmamakla birlikte \%33,0 oranla katılımcların aylık gelir düzeyinin 0-3.000 TL arasında olduğu görülmektedir. 
Tablo 1. Katılımcların demografik bilgileri.

\begin{tabular}{|c|c|c|}
\hline Cinsiyet & $n$ & $\operatorname{Oran}(\%)$ \\
\hline Kadm & 138 & 65,1 \\
\hline Erkek & 74 & 34,9 \\
\hline Yaş & $n$ & Oran (\%) \\
\hline $18-24$ & 54 & 25,5 \\
\hline $25-34$ & 85 & 40,1 \\
\hline $35-44$ & 41 & 19,3 \\
\hline $45-54$ & 18 & 8,5 \\
\hline $55-64$ & 9 & 4,2 \\
\hline 65 ve üzeri & 5 & 2,4 \\
\hline Ĕgitim Durumu & $n$ & Oran (\%) \\
\hline ìlköğretim & 1 & 0,5 \\
\hline Ortaöğretim & 6 & 2,8 \\
\hline Lise & 12 & 5,7 \\
\hline Önlisans & 21 & 9,9 \\
\hline Lisans & 128 & 60,4 \\
\hline Yüksek Lisans & 34 & 16,0 \\
\hline Doktora & 10 & 4,7 \\
\hline Çalışma Durumu & $n$ & $\operatorname{Oran}(\%)$ \\
\hline Öğrenci & 54 & 25,5 \\
\hline Çallşıyor & 122 & 57,5 \\
\hline Çalışmıyor & 18 & 8,5 \\
\hline Emekli & 18 & 8,5 \\
\hline Ayllk Gelir Düzeyi & $n$ & Oran (\%) \\
\hline $0-3.000 \mathrm{TL}$ & 70 & 33,0 \\
\hline $3.001-5.000 \mathrm{TL}$ & 61 & 28,8 \\
\hline $5.001-10.000 \mathrm{TL}$ & 59 & 27,8 \\
\hline 10.001 TL ve üzeri & 22 & 10,4 \\
\hline Toplam & 212 & 100,0 \\
\hline
\end{tabular}

\section{Tüketim alsşkanlıklan ve tüketim mekanı tercihine ilişkin bulgular}

Tablo 2 verilerine göre, katılımclların $\% 86,3$ oranla büyük bir çoğunluğunun Covid-19 salgınından sonra tüketim alışkanlıklarının değiştiği; katılımcıların \%65,6'sının tüketim mekanı tercihlerinin değiştiği görülmektedir. Bu durumda, ele alınan örneklem kapsamında, tüketicilerin tüketim alışkanlıklarında ve tüketim mekanı tercihinde değişikliklere yöneldiği söylenebilir. Bu durumda 1. ve 2. hipotezin boş hipotezleri (H0) reddedilmiş, alternatif hipotezleri (HA) kabul edilmiştir.

Tablo 2. Covid-19 salgınından sonra tüketim alışkanlıkları ve tüketim mekanı tercihi değişme durumu.

\begin{tabular}{lll}
\hline Tüketim alışkanlı̆̆ı değişme durumu & $n$ & Oran (\%) \\
\hline Evet & 183 & 86,3 \\
Hayır & 29 & 13,7 \\
\hline Tüketim mekanı tercihinde değişme durumu & $n$ & Oran (\%) \\
\hline Evet & 139 & 65,6 \\
Hayır & 73 & 34,4 \\
\hline Toplam & $\mathbf{2 1 2}$ & $\mathbf{1 0 0 , 0}$ \\
\hline
\end{tabular}


Tüketim ihtiyacı ve alışkanlıkları değişenler için hangi tür alışkanlıklarının en çok değiştiği ve neden değiştiği sorulmuş, tüketim ihtiyacı ve alışkanlıkları değişmeyen kişilerin yanıtları frekans dağılımı değerlendirmesine alınmamıştır. Bu doğrultuda, Tablo 3'e göre, tüketim ihtiyacı ve alışkanlıkları değişen tüketiciler için \%30,7 oranla temizlik/hijyen malzemeleri ve \%25 oranla gıda ihtiyacı en çok artış göstermiştir. Hem temizlik/hijyen malzemesi hem de gida ihtiyacının artmasının Covid-19 virüsünün etkileri ile doğrudan ilişkili olduğunu söylemek mümkündür. Diğer taraftan \%39,6 oranla evde daha çok vakit geçirilmesi ve ona çok yakın olan \%38,7 oranla sağlık için ihtiyaç duyulması tüketim alışkanlıklarının ve ihtiyaçlarının değişmesinin en etkili nedenleri olarak belirlenmiştir. Bu sonuçlar, tüketim ihtiyaçlarının değişmesinde olduğu gibi, Covid-19 virüsünün etkileri ile doğrudan ilişkili olarak yorumlanabilir. Bu sonuçların Covid-19 virüsünün gündelik hayatta sebep olduğu değişiklikler ile tutarlılık gösterdiği söylenebilir.

Tablo 3. Covid-19 salgınından sonra en çok değişen tüketim ihtiyacı ve ihtiyacın değişme nedenleri.

\begin{tabular}{lll}
\hline Değişen ihtiyaç türü & Frekans & Oran (\%) \\
\hline Temizlik/hijyen malzemeleri & 65 & 30,7 \\
Gıda & 53 & 25,0 \\
Ev ihtiyaçları & 22 & 10,4 \\
Giyim & 18 & 8,5 \\
Să̆lık ürünleri (ilaç vb.) & 13 & 6,1 \\
Teknolojik ürünler & 6 & 2,8 \\
Kozmetik & 3 & 1,4 \\
Mobilya ve ev aksesuarları & 2 & 0,9 \\
\hline Anket dışı kalan & 30 & 14,2 \\
\hline Toplam & $\mathbf{2 1 2}$ & $\mathbf{1 0 0 , 0}$ \\
\hline İhtiyacın değişme nedeni & Frekans & Oran (\%) \\
\hline Evde daha çok vakit geçirilmesi & 84 & 39,6 \\
Sağllk için ihtiyaçduyulması & 82 & 38,7 \\
Ekonomik koşullar & 10 & 4,7 \\
Boş zamanların değerlendirilmesi & 4 & 1,9 \\
Basın ve sosyal medyadan etkilenme & 2 & 0,9 \\
\hline Anket dışı kalan & 20 & 14,2 \\
\hline Toplam & $\mathbf{2 1 2}$ & $\mathbf{1 0 0 , 0}$ \\
\hline
\end{tabular}

Katılımcılara Covid-19 salgınından önce ve sonrasında tüketim mekanı tercihleri ve tercih etme nedenleri sorulmuştur (Tablo 4). Katılımclar Covid19 öncesinde tüketim için \%52,4 oranla en çok marketten ihtiyaçlarını karşılarken, $\% 6,6$ oranla en az online alışveriş siteleri ve uygulamalarını tercih ettiklerini belirtmişlerdir. Diğer taraftan tüketim mekanı tercihlerinde en büyük etkenin $\% 39,6$ oranla kolay erişilebilir olması olarak ifade edilmiştir. Covid-19 sonrası tüketim mekanı tercihi değişen katılımcıların \%37,7'si online 
alışveriş siteleri ve uygulamalarında alışverişe yönelmişler ve tüketim mekanı tercihlerinin değişmesinde en büyük etkeni \%32,1 oranla evden dışarıya çıkma ihtiyacını azaltması olarak belirtmişlerdir. Covid-19 salgını sonrasında tüketim mekanı tercihi değişmeyen kişilerin yanıtları frekans dağılımı değerlendirmesine alınmamıştır. Bu iki sonuç kendi içerisinde tutarlılık göstermektedir. Elde edilen verilere göre, Covid-19 salgınından sonra sosyal mesafe kurallarına uymaya özen gösteren ve evde geçirdiği vakit artan tüketicilerin online alışverişe yönelmekte olduğunu söylemek mümkündür.

Tablo 4. Covid-19 öncesi ve sonrasında en çok tercih edilen tüketim mekanı ve tüketim mekanını tercih etme nedeni.

\begin{tabular}{|c|c|c|c|c|}
\hline \multirow[b]{2}{*}{ Tüketim mekanı } & \multicolumn{2}{|c|}{ Covid-19 öncesi } & \multicolumn{2}{|c|}{ Covid-19 sonrası } \\
\hline & Frekans & Oran (\%) & Frekans & Oran (\%) \\
\hline Market & 111 & 52,4 & 44 & 20,8 \\
\hline Alışveriş merkezleri & 52 & 24,5 & 0 & 0,0 \\
\hline $\begin{array}{l}\text { Sokaktaki dükkanlar (bakkal, eczane, firın } \\
\text { vb.) }\end{array}$ & 19 & 9,0 & 6 & 2,8 \\
\hline Pazar & 16 & 7,5 & 4 & 1,9 \\
\hline Online alışveriş siteleri ve uygulamaları & 14 & 6,6 & 80 & 37,7 \\
\hline Anket dışı kalan & - & - & 78 & 36,8 \\
\hline Toplam & 212 & 100,0 & 212 & 100,0 \\
\hline Tüketim mekanın tercih etme nedeni & Frekans & Oran $(\%)$ & Frekans & Oran $(\%)$ \\
\hline Kolay erişilebilir olması & 84 & 39,6 & 39 & 18,4 \\
\hline Şehir içinde ulaşım kolayliğı & 53 & 25,0 & 6 & 2,8 \\
\hline Mekanın sunduğu sosyal olanaklar & 31 & 14,6 & 2 & 0,9 \\
\hline Güvenli, denetimli bir mekan olması & 14 & 6,6 & 6 & 2,8 \\
\hline Mekanın fiziksel özellikleri & 11 & 5,2 & 2 & 0,9 \\
\hline Sağllklı bir ortam sunması & 10 & 4,7 & 10 & 4,7 \\
\hline Evden dışarıya çıkma ihtiyacını azaltması & 9 & 4,2 & 68 & 32,1 \\
\hline Anket dışı kalan & - & - & 79 & 37,3 \\
\hline Toplam & 212 & 100,0 & 212 & 100,0 \\
\hline
\end{tabular}

Tablo 5'e göre, Covid-19 salgınından sonra katılımcıların sağlık açısından en güvenli buldukları mekan $\% 59,9$ oranla online alışveriş siteleri ve uygulamalarıdır. Bu sonuç diğer sonuçlarla benzerlik göstermekte ve Covid-19 virüsü sebebiyle tüketicilerin evden dişarıya çıkmadan sanal ortamdan gerçekleştirilen alışverişin sağlık açısından daha güvenli olarak değerlendirdiği görülmektedir. Bu durumda, 3. hipotezin boş hipotezi (H0) reddedilmiş, alternatif hipotezi (HA) kabul edilmiştir. Diğer taraftan Tablo 4 verileri de bu hipotezi destekler niteliktedir. 
Tablo 5. "Sağlıklı" olarak nitelendirilen tüketim mekanı tablosu.

\begin{tabular}{lll}
\hline Tüketim mekanı & Frekans & Oran (\%) \\
\hline Market & 54 & 25,5 \\
Alışveriş merkezleri & 3 & 1,4 \\
Sokaktaki dükkanlar (bakkal, eczane, firın vb.) & 14 & 6,6 \\
Pazar & 14 & 6,6 \\
Online alışveriş siteleri ve uygulamaları & 127 & 59,9 \\
\hline Toplam & $\mathbf{2 1 2}$ & $\mathbf{1 0 0 , 0}$ \\
\hline
\end{tabular}

Anket kapsamında katılımcılara ayrıca Covid-19 salgını sonrasında tüketim mekanında bekledikleri fiziksel ve sosyal özellikler ve düzenlemeler sorulmuştur (Tablo 6). Elde edilen ortalamalara göre, kesinlikle katıllyorum ifadeleri değerlendirildiğinde Covid-19 salgınından sonra tüketim mekanlarında mekanın temiz ve hijyenik olması, mekanın iyi havalandırılması ve mekanda kişi sınırlaması olması beklendiği görülmektedir. En düşük ortalamayı alan ifade olan, Covid-19 salgınından sonra kullanılan tüketim mekanında sinema, restoran, kafeterya, çocuk oyun alanı gibi farklı kullanım alanlarının olması önemlidir ifadesi ortalama olarak kararsızım yanıtı almıştır. Bu verilere göre, Covid-19 salgını sürecinde yeni önceliklerin ve davranışların ortaya çıkması sonucunda kullanıcıların tüketim mekanlarında önceki uygulamalardan farklı fiziksel ve sosyal düzenlemelerin yapılmasını beklediği görülmektedir. Katılımcılar tüketim mekanında sosyal alan kullanımının ön plana çıkarılması yerine mekanın temiz ve hijyenik olmasına, iyi havalandırılmasına, kişi sınırlaması olmasına, açık hava ve yeşil alan kullanımı olmasına veya tüketimin sanal ortamdan gerçekleştirilmesine önem vermektedir. Bu nedenle, pandemi sürecinde edinilen yeni alışkanlıkların tüketim mekanlarında bazı kalıcı değişikliklere neden olacağı öngörülmektedir.

Tablo 6. Tüketim mekanının fiziksel ve sosyal özelliklerinin düzenlenmesine dair tablo.

\begin{tabular}{|c|c|c|c|c|c|c|c|c|}
\hline & 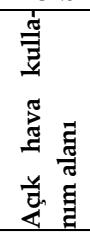 & 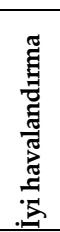 & 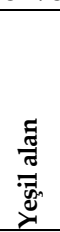 & 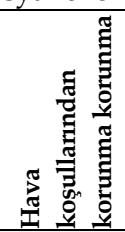 & 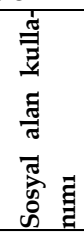 & 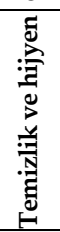 & 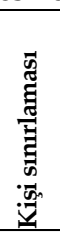 & 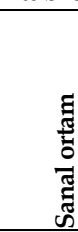 \\
\hline & L1 & L2 & L3 & L4 & L5 & L6 & L7 & L8 \\
\hline Değerlendirilen & 208 & 207 & 210 & 208 & 208 & 210 & 209 & 207 \\
\hline $\begin{array}{l}\text { Anket dış1 } \\
\text { kalan }\end{array}$ & 4 & 5 & 2 & 4 & 4 & 2 & 3 & 5 \\
\hline Ortalama & 4,27 & 4,70 & 3,98 & 3,90 & 2,74 & 4,80 & 4,54 & 4,09 \\
\hline
\end{tabular}

Araştırma hipotezleri sonuçları Tablo 7'de özetlenmiştir. Covid-19 salgını ortaya çıktığından beri sadece gündelik hayat değişikliğe uğramamış, aynı 
zamanda gündelik hayattaki değişiklikler tüketim alışkanlıkları ve tüketim mekanı tercihlerinde de farklı yönelimlerde bulunulmasına neden olmuştur. Değişen gündelik hayat alışkanlıkları sebebiyle, sermaye kendi sürekliliğini sağlamak ve tüketimi devamlı kılmak amaciyla yeni pazarlama stratejileri geliştirmiş ve sağlık açısından daha güvenli olduğunu vurgulayarak sanal tüketim mekanlarına yönelimi arttırmıştır. Evlerde daha çok vakit geçiren bireyler internet aracıllğ 1 ile istediği saatte istediği her şeye ulaşabildiği gibi alışverişi de evinden çımadan yapabilme şansı bulmuştur. Anket sonuçları değerlendirildiğinde tüketim mekanı tercihi konusunda yönelim değişikliklerinin olduğu oldukça açıtır. Bu bağlamda, bazı mevcut tüketim mekanları hala tercih edilirken bunların fiziksel ve sosyal koşullarında bazı değişikliklerin gerekli olduğunu, sanal tüketim ortamıyla ilişkili olarak ise yeni mekansal düzenlemelere ihtiyaç duyulduğunu söylemek mümkündür.

Tablo 7. Araştırma hipotezlerinin sonuçları.

\begin{tabular}{|c|c|}
\hline Hipotezler & Sonuç \\
\hline $\begin{array}{l}\text { 1-H0: Covid-19 salginnndan sonra tüketim ihtiyaçlan ve alı̧sanlıkla- } \\
\text { rnda değişiklik yoktur. }\end{array}$ & Reddedildi \\
\hline $\begin{array}{l}\text { HA: Covid-19 salgınından sonra tüketim ihtiyaçları ve alıskanlıklarında değişiklik } \\
\text { vardır. }\end{array}$ & Kabul edildi \\
\hline $\begin{array}{l}\text { 2-H0: Covid-19 salgınndan sonra tüketim mekanı tercihinde değişik- } \\
\text { lik yoktur. }\end{array}$ & Reddedildi \\
\hline HA: Covid-19 salgmnndan sonra tüketim mekanı tercihinde değişiklik vardır. & Kabul edildi \\
\hline $\begin{array}{l}\text { 3-H0: Covid-19 salgınından sonra tüketim mekanları arasında online } \\
\text { alı̧verişsiteleri ve uygulamaları sağllk açısından daha güvenli bulun- } \\
\text { mamaktadır. }\end{array}$ & Reddedildi \\
\hline $\begin{array}{l}\text { HA: Covid-19 salgınından sonra tüketim mekanları arasında online alışveriş site- } \\
\text { leri ve uygulamaları sağlık açısından daha güvenli bulunmaktadır. }\end{array}$ & Kabul edildi \\
\hline
\end{tabular}

Covid-19 salgını nedeniyle gıda, sağlık, giyim ve diğer ihtiyaçlar için sanal tüketim ortamlarında alışverişin artması ve önümüzdeki dönemlerde de artacağı beklentisi sebebiyle yeni mekansal örgütlenmelere ihtiyaç duyulmaktadır. Bazı büyük firmalar karantina döneminde evden yapılan online alışverişlerin artması sebebiyle mağazalarını kapatarak online alışveriş ile satışlarına devam edeceklerini bildirmişlerdir (Cumhuriyet, 2020). Bu durum, uluslararası düzeyde ürünleri saklamak için depolama alanlarını, taşımak için karayolu ve havaalanı gibi yeni mekansal düzenlemeleri gerekli kılmaktadır (Yırtıcı, 2002, s.37). Sistemin gereklilikleri doğrultusunda değişen gündelik hayata uyum sağlamak için mimarlık disiplininde ve inşaat sektöründe yeni mekansal düzenlemelerin zaman içinde gerçekleştirilmesi kaçınılmazdır. 


\section{Tartışma ve Sonuç}

Küreselleşme ile serbest ekonomi piyasası gelişen teknolojik imkanlardan yararlanarak 20. yüzyılın son çeyreğinden itibaren ülkeler arası ulaşım kısıtlamasını ortadan kaldırmış; sosyal, kültürel, ekonomik iletişim ve etkileşimi arttırmıştır. Tüm dünya vatandaşlarına yönelik gerçekleştirilen ticaret ve pazarlama stratejileri farklı kültürlerin ortak davranışlarda ve tercihlerde bulunmalarına ve evrensel bir yaşam biçiminin oluşmasına sebep olmuştur. $\mathrm{Bu}$ durum, bütün dünyada aynı üretim ve tüketim anlayışına sahip bireylerin ve sunduğu farklı olanaklar ile tüketimi hayatın bir parçası haline getiren tüketim mekanlarının ortaya çıkmasına neden olmuştur.

Bireylerin hayatındaki eksiklikleri, gündelik hayattaki hoşnutsuzluklarını tüketim yoluyla çözebilecekleri algısının yaratılması günümüz tüketim toplumunu şekillendiren durumlardan biridir. Tüketimi devamlı kılmayı hedefleyen pazarlama taktikleri, yeni ürünler ve insanların duyguları arasında ilişki kurmaktadır. Bu bağlamda, üretimin ve tüketimin devamlı hale gelmesi için kitle iletişim araçları, medya, reklamlar ve diğer pazarlama yöntemleri tüketicilerin duygusal yönleriyle bağ kurarak tüketimin yaşam tarzının bir parçası ve amacı haline gelmesini hedeflemektedir. Bunu gerçekleştirmek için tüketim mekanları değişen hayat tarzı ve ihtiyaçlara göre şekillendirilmekte, yeni mekansal düzenlemeler gerçekleştirilmektedir. Günümüzde popüler olan tüketim mekanları bir yandan bireylerin temel ihtiyaçlarının giderilmesini sağlarken, diğer yandan sosyalleşme ve kendilerini kantlama ihtiyaçlarına da cevap vermektedir.

Covid-19 salgın süreci dünyadaki bütün toplumların gündelik hayatında değişikliklere sebep olmuştur. Toplumların önceliklerinin ve alışkanlıklarının farklılaşması ve gelecekte kalıcı hale gelebilecek bazı değişiklikler yaşıyor olması bir geçiş döneminde olduğumuzu göstermektedir. Çalışmada, tüketim kavramı sosyal, kültürel, ekonomik, mekansal olarak ele alınmış ve Covid-19 öncesi ve sonrasında değişen durumu incelenmiştir. Çalışmanın amacı, Covid-19 virüsünün neden olduğu pandemi sürecinin Türk toplumunun tüketim alışkanlıkları ve tüketim mekanı tercihlerinde değişikliğe neden olup olmadığını sorgulamaktır. Bu amaçla tüketim kültürü, tüketim alışkanlıkları, tüketim mekanları ile ilgili kavramsal bir çerçeve oluşturulduktan sonra Covid-19 salgınının etkilerini anlamaya yönelik anket çalışması gerçekleştirilmiştir. Covid-19 döneminde farklı önceliklerin ve tercihlerin oluşması tüketim alışkanlıkları ve tüketim mekanı tercihinde farklı dinamiklerin ön 
plana çıkmasına neden olmuştur. Çalışmanın sonucunda elde edilen bulgulara göre, bireylerin tüketim alışkanlıklarının ve tüketim mekanı tercihlerinin değiştiği, online alışveriş sitelerini ve uygulamalarını sağlık açısından daha güvenli buldukları ve alışveriş için kullandıkları mekanlarda fiziksel ve sosyal düzenlemelerin yapılmasına önem verdikleri görülmektedir. Bu doğrultuda, pandemi dönemi sonrasında kalıcı hale gelebilecek yeni tüketim alışkanlıklarının oluşması nedeniyle yeni tüketim mekanlarının ortaya çıkması ve mevcut tüketim mekanlarında fiziksel ve sosyal düzenlemelerin yapılması kaçınılmaz olacaktır. Aynı zamanda, gıda, giyim vb. ihtiyaçları gidermeye yönelik çevrimiçi alışveriş talebinin artması ve çevrimiçi alışverişin daha sağlıklı bulunması kentsel mekanda bazı düzenlemelerin yapılmasını gerekli kılmaktadır. Kentsel mekanda çevrimiçi alışverişi olanaklı kılacak mağaza, depo, dağıtım merkezleri, limanlar, havaalanları, karayolları ve dağıtım ağları gibi yeni mekansal organizasyonların yapılması gerekmektedir. Diğer taraftan kentte yer alan mevcut alışveriş merkezlerinin kapalı devre yapısının değişmesi ve açık, yarı açık mekanlarla beslenen, sokak kültürünü yeniden hatırlatan mimari çözümlerin kentsel mekanda yer bulması bir zorunluluktur. Bu anlamda, çalışma sonuçları bireylerin daha sağlıklı koşullarda tüketim eylemlerini gerçekleştirecekleri fiziksel ve çevrimiçi mekanların düzenlenmesi ve paralel olarak kentsel yapılanmanın güçlendirilmesi gerekliliğini ortaya koymaktadır.

Bu çalışma Covid-19 salgını sürecinin gündelik yaşamı ve hayat tarzını etkilemesi sebebiyle üretimde, tüketimde ve mekansal örgütlenmelerde kalıcı değişikliklere neden olabileceğini göstermektedir. Bu bağlamda Covid-19 salgın süreci sonrasında tüketicinin yeni alışkanlıkları ve tercihleri doğrultusunda mimarlığın ve yapım sektörünün tüketim kültürü ve tüketim toplumu içinde nasıl bir konumunun ve rolünün olacağ üzerine odaklanılmasının bilim alanına katkı sağlayacağı düşünülmektedir. Gelecekte mimarlık disiplininin ve yapım sektörünün değişen yaşam koşullarına uygun olacak şekilde tüketim mekanlarını düzenlenmesine yönelik çalışmaların yapılması ve olası düzenlemelerin toplum üzerindeki etkilerinin araştırılması önerilmektedir. 


\section{Extended Abstract}

\section{The Effect of Covid-19 Pandemic Period on Consumer's Consumption Habits and Perspective On Consumption Spaces}

\author{
Birsu Ece Kaya \\ ORCID: 0000-0001-8834-6732
}

\author{
İkbal Erbaş \\ ORCID: 0000-0002-6327-1399
}

Production and consumption activities take place continuously in life and are affected by changes in everyday life. Capitalism and globalization affect the needs and habits of consumers in order to ensure the continuity of the system, make the production and consumption cycle continuous and organize it according to new needs and habits. In parallel with the social, cultural and economic changes in societies, the architecture and construction industry organize and transform consumption spaces in line with needs, demands and conditions. Changes in consumption tendencies affect products and consumption spaces, as well as changes in consumption spaces and methods affect the lifestyle and consumption tendencies of societies. The "Covid-19" virus, which emerged in China in 2019, has caused radical changes in all areas in the world, and societies have had to make unplanned and rapid changes in their daily lives in order to protect themselves from the epidemic. In order to ensure social isolation and protect themselves against the virus, it has become inevitable to change the consumption habits, priorities and consumption space preferences of individuals. The aim of this study is to question the change in consumption habits and consumption space preferences of individuals before and after the pandemic, due to the Covid-19 virus and the epidemic process affecting daily life. The reflections and regulatory effects of the Covid-19 pandemic period in the productionconsumption processes and spatial arrangements still continue. In this context, duties fall on the professions such as advertising, marketing, architecture and construction sector in line with the tendencies and habits that can become permanent. The original aspect of this study is to reveal the physical and social 
characteristics that are expected to be changed or improved in existing consumption spaces by questioning the change in consumption habits and consumption space preferences in Turkish society before and after the Covid-19 pandemic period.

Throughout history, people have organized consumption spaces where they can realize their consumption activities. In today's society, consumption spaces such as shopping malls are arranged in a way that make it possible to meet social and cultural needs in addition to meeting basic needs in order to maintain consumption. At the same time, the development of technological opportunities has enabled the regulation of virtual consumption spaces, and they have made it possible for individuals to access products quickly and easily in the busy pace of life. However, the emergence of virtual shopping places does not mean the disappearance of physical spaces. In order for virtual shopping to be possible, different physical spaces such as shops, stores, warehouses, distribution centers and transportation places that will provide distribution via highway, airway and seaway are needed.

In this study, after creating a conceptual framework regarding consumption culture, consumption habits and consumption spaces, the results of the survey applied to evaluate the effects of the Covid-19 pandemic process are included. Since the opportunity to meet face-to-face with the participants is low due to the pandemic, the survey was prepared online and sent to individuals living in various cities of Turkey with the snowball sampling method over the internet. The population of the study consisted of students, working, unemployed and retired people over the age of 18. IBM SPSS statistical program was used to analyze the data obtained from the survey that questions consumption habits and consumption space preferences, the changes in these preferences and the demands in terms of health. Frequency distribution analysis was applied to analyze demographic information and hypotheses.

According to the findings obtained as a result of the survey, it is seen that the consumption habits and consumption space preferences of individuals have changed after the Covid-19 epidemic. In addition, it can be said that they find online shopping sites and applications safer in terms of health and they give importance to physical and social arrangements in order to take into account criterias such as cleanliness, hygiene and ventilation in the spaces they currently use for shopping. In this sense, it can be said that the results obtained from the survey are consistent with the changes caused by the Covid-19 virus in daily life. At the same time, as a result of the emergence of new priorities and preferences during the Covid-19 epidemic process, it is seen that users have 
different tendencies in consumption spaces and demand new physical and social arrangements in existing consumption spaces, unlike previous practices. For this reason, it is predicted that the priorities and habits acquired during the pandemic period will cause permanent changes and regulations in consumption areas.

Giving priority to physical and social isolation in order to protect from the epidemic causes changes in society's behaviors and preferences. Trends that are becoming permanent are expected to be effective in the consumption structure, behaviors and spatial preferences of societies, especially in the social structure. Consumption spaces are organized according to changing lifestyles and needs, and new spatial arrangements are constantly being made. Due to the pandemic, it is expected that new spatial arrangements will be implemented to ensure storage and distribution in the background of virtual consumption spaces, and improvements will be made in accordance with new expectations and conditions, prioritizing criterias such as cleanliness, hygiene, and outdoor use in existing consumption spaces. This study focuses on the position and role of the architecture and construction industry in the consumption culture and consumption society in line with the new habits and preferences that are expected to become permanent after the pandemic, by questioning consumption habits and preferences before and after the Covid-19 pandemic period. In this direction, it is suggested that researches should be carried out on the regulation and development of consumption spaces, taking into account the expectation of the society and its effects on the society, in accordance with the changing life conditions for future studies.

\section{Kaynakça/References}

Arslan Avar, A. (2009). Lefebvre'nin üçlü -algilanan, tasarlanan, yaşanan mekan- diyalektiği. Mimarlar Odası Ankara Şubesi Dosya 17, Aralık, 7-16.

Asiamah, N., Mensah, H. K. ve Oteng-Abayie, E. F. (2017). General, target, and accessible population: Demystifying the concepts for effective sampling. The Qualitative Report, 22(6), 1607.

Baudrillard, J. (1997). Tüketim toplumu. Tutal, N. ve Keskin, F. (Çev.), İstanbul: Ayrıntı Yayınları.

Baudrillard, J. (2002). Tüketimin tanımına doğru. Çă̆daş Dünya Sorunlar Dizisi 3 Mimarlik ve Tüketim. Benedict, J. (İngilizce Çev.), İstanbul: Boyut Yayın Grubu, 67-72.

Bayır, T. (2021). Koronavirüs (COVID-19) ile yeni dijital dünyada değişen tüketici tercihleri. OPUS Uluslararası Toplum Araştırmaları Dergisi, 17(Pandemi Özel Sayısı), 1-1. 
Böke, K. (Ed.). (2017). Sosyal bilimlerde araştırma yöntemleri (5. Baskı). İstanbul: Alfa Yayınları.

Can, H., Aşan Azizoğlu, Ö. ve Miski Aydın, E. (2015). Örgütsel davranış. Ankara: Siyasal Kitabevi.

Cumhuriyet. (2020, 1 Ekim). Ünlü giyim firması Covid-19 nedeniyle yüzlerce mağazasını kapatacak. Erişim adresi: https://www.cumhuriyet.com.tr/haber/unlu-giyim-firmasi-covid-19-nedeniyle-yuzlerce-magazasini-kapatacak-1770348

Çakıroğlu, K. I., Pirtini, S. ve Çengel, Ö. (2020). Covid-19 sürecinde ve post-pandemi döneminde yaşam tarzı açısından tüketici davranışlarının değişen eğilimi üzerine kavramsal bir çalışma. İstanbul Ticaret Üniversitesi Sosyal Bilimler Dergisi Covid-19 Sosyal Bilimler Özel Sayısı (Özel Ek). 81-103.

Çevik Tekin, İ. (2020). Pandemi sürecinde değișen tüketici davranışları. Business and Management Studies: An International Journal, 8(2), 2331-2347.

Çınar, R. ve Çubukçu, İ. (2009). Tüketim toplumunun şekillenmesi ve tüketici davranışları -karşılaştırmalı bir uygulama-. Atatürk Üniversitesi Sosyal Bilimler Enstitüsü Dergisi, 13(1), 277-300.

Danışmaz, A. T. (2020). Covıd-19 salgınının tüketicilerin online alışveriş tercihine etkisi. Sosyal Bilimler Araştırma Dergisi, 9(2), 83-90.

Duygun, A. (2020). COVID-19 pandemisi sırasında tüketicilerin yaşam tarzlarının değerlendirilmesi. Econder Uluslararası Akademik Dergi, 4(1), 232-247.

Erbaş, İ. (2021). Covıd-19 pandemi sürecinde olan ... biten ... ve geride kalan... İzmir: Serüven Yayınevi.

Giddens, A. (1994). Modernliğin sonuçları. İstanbul: Ayrıntı Yayınları.

İnce, M. ve Kadığlu, C. T. (2020). Tüketicilerin Covid19 (Korona) virüsüyle artan stoklama isteğinin online satın alma davranışına etkisi. OPUS-Uluslararası Toplum Araştırmalar Dergisi, 16(29), s.1875-1906.

Kadıoğlu, Z. K. (2014). Tüketim iletişimi: Süreçler, algılar ve tüketici. İstanbul: Pales Yayıncllik.

Kayabaşı, E. T. (2020). COVID-19'un piyasalara ve tüketici davranişlarina etkisi. Avrasya Sosyal ve Ekonomi Araştırmalarn Dergisi, 7(5), 15-25.

Kotler, P. (2020). The consumer in the age of coronavirus. Marketing Journal. Erişim adresi: https://www.marketingjournal.org/the-consumer-in-the-age-of-coronavirus-philip-kotler/

Kotrlik, J. W. K. J. W. ve Higgins, C. C. H. C. C. (2001). Organizational research: Determining appropriate sample size in survey research appropriate sample size in survey research. Information technology, learning, and performance journal, 19(1), 43.

Lefebvre, H. (2010). Gündelik hayatın eleştirisi I. İstanbul: Sel Yayıncllık.

Özkalp, E. ve Kırel, Ç. (2018). Örgütsel davranış (8. Baskı). Bursa: Ekin Basım Yayın Dağıtim.

Özbek Sönmez, İ. (2002). Yapısal dönüşümler sürecinde yerel ve yerel üstü ilişkilerin mekansal yansımaları. Ege Mimarlik, 40-41, 32-36. 
Özcü, A. E. ve Atanur, G. (2020). Kovıd-19 pandemisinin kent yaşamına etkisi: Kamusal alan üzerine değerlendirmeler. Paradoks Ekonomi Sosyoloji ve Politika Dergisi, 16(2), 237-250.

Yırtıcı, H. (2002). Tüketimin mekansal örgütlenmesinin ideolojisi. Çă̆daş Dünya Sorunları Dizisi 3 Mimarlı ve Tüketim. İstanbul: Boyut Yayın Grubu, 9-38.

Zeren, D. ve Gökdağlı, N. (2017). Satın alma motivasyonları: Tüketicilerin sanal kompülsif davranışları üzerine bir araştırma. Dumlupınar Üniversitesi Sosyal Bilimler Dergisi Pazarlama Kongresi Özel Sayısı. 41-58. 